\title{
Increase in Discharge Capacity of Li Battery Assembled with Electrochemically Prepared $\mathrm{V}_{2} \mathrm{O}_{5}$ /polypyrrole-composite-film Cathode ${ }^{\dagger}$
}

\author{
Youna Kim, Joo-Seong Kim, Minh-Triet Thieu, Hung-Cuong Dinh, In-Hyeong Yeo, ${ }^{\ddagger}$ Won II Cho, ${ }^{\S}$ and Sun-il Mho \\ Division of Energy Systems Research, Ajou University, Suwon 443-749, Korea. *E-mail: mho@ajou.ac.kr \\ ${ }^{\ddagger}$ Department of Chemistry, Dongguk University, Seoul 100-715, Korea \\ ${ }^{\S}$ Advanced Battery Center, Korea Institute of Science and Technology, Seoul 130-650, Korea \\ Received July 16, 2010, Accepted September 14, 2010
}

\begin{abstract}
Flexible composite films of $\mathrm{V}_{2} \mathrm{O}_{5}$ and conductive polypyrrole $\left(\mathrm{V}_{2} \mathrm{O}_{5} / \mathrm{PPy}\right)$ were grown by facile electrochemical polymerization, wherein an anodization potential was applied to the substrate electrode in an electrolyte solution containing pyrrole monomer and dispersed $\mathrm{V}_{2} \mathrm{O}_{5}$ particles. The coating of polypyrrole (PPy) on the surface of $\mathrm{V}_{2} \mathrm{O}_{5}$ particles was induced by the oxidative catalytic action of $\mathrm{V}_{2} \mathrm{O}_{5}$ during the electrochemical polymerization of pyrrole. $\mathrm{PPy}$ in the composite film connects the isolated $\mathrm{V}_{2} \mathrm{O}_{5}$ particles. This results in the formation of conductive networks in the composite film cathode, thereby enhancing the $\mathrm{Li}^{+}$ion diffusion to the surface of the isolated $\mathrm{V}_{2} \mathrm{O}_{5}$ particles and thus increasing the accessibility of the $\mathrm{Li}^{+}$ions. The specific capacity tests of the Li rechargeable batteries revealed that the discharge capacity of this composite film cathode was higher, i.e., $497 \mathrm{mAhg}^{-1}$, than that of $\mathrm{V}_{2} \mathrm{O}_{5} / \mathrm{PPy}_{\text {powder }}$ or pristine $\mathrm{V}_{2} \mathrm{O}_{5}$.
\end{abstract}

Key Words: Inorganic-organic composite film, Electrochemical preparation, Conducting polymer film, Li battery

\section{Introduction}

Layer-structured metal oxides have attracted much attention because of their potential application in lithium batteries owing to their outstanding structural flexibility with regard to lithium insertion/desertion. ${ }^{1-7}$ Vanadium pentoxide has been intensively studied as a cathode material in lithium batteries because of its structural reversibility, thermal stability, and high theoretical capacity in lithium intercalation/deintercalation. ${ }^{1-3}$ In order to exploit the nanoscale thin solid-phase layered structures for increasing the capacity of rechargeable lithium batteries, amorphous $\mathrm{V}_{2} \mathrm{O}_{5}$ materials such as aerogels or xerogels have been used as intercalation cathodes. ${ }^{6,7}$ However, the low crystallinity of $\mathrm{V}_{2} \mathrm{O}_{5}$ gels or the presence of water within the gels has often proved to be a major stumbling block in providing consistent electrochemical properties as battery materials. These adverse effects often offset the advantage of having an extremely high surface-to-volume ratio for amorphous $\mathrm{V}_{2} \mathrm{O}_{5}$ materials. In addition to the high surface to volume ratio, the specific capacities can be increased by enhancing the Li accessibility or by increasing the conductivity of the electrode materials. The kinetic barriers induced by the limited Li ion accessibility within cathodes can be minimized by embedding inorganic electrode materials in conductive organic materials. Conductive polymers are attractive electrode materials owing to their electrochemical activities; ${ }^{8,9}$ (i) they can be charged and discharged by a redox reaction involving lithium ions or counter anions of the electrolyte, (ii) they can be used to coat crystalline surfaces to enhance the electrical conductivity, and (iii) they can connect isolated crystalline particles with improved mechanical flexibility. Among various conductive polymers, PPy has been used extensively

\footnotetext{
${ }^{\top}$ This paper is dedicated to Professor Hasuck Kim for his outstanding contribution to electrochemistry and analytical chemistry.
}

because of its high electrical conductivity, stability in electrochemical environments, and relatively easy preparation methods. ${ }^{10-12}$ The composite powders of inorganic crystallites with polypyrrole have been investigated to overcome the inherently low electronic conductivity of inorganic crystallites and to obtain favorable electrochemical characteristics. ${ }^{13-17}$ In the present study, $\mathrm{V}_{2} \mathrm{O}_{5}$ and polypyrrole composite $\left(\mathrm{V}_{2} \mathrm{O}_{5} / \mathrm{PPy}\right)$ films were grown by an electrochemical polymerization method wherein an anodic potential was applied to a substrate electrode in a solution containing a pyrrole monomer and dispersed $\mathrm{V}_{2} \mathrm{O}_{5}$ particles. The use of these composite films increases the discharge capacity owing to their high conductivity, better $\mathrm{Li}^{+}$-ion accessibility, and improved diffusion pathways. Mechanically flexible $\mathrm{V}_{2} \mathrm{O}_{5}$ and polypyrrole composite films offer cyclic stability during the expanding and shrinking of $\mathrm{V}_{2} \mathrm{O}_{5}$ particles. Recently, there have been a few attempts to develop mechanically flexible rechargeable batteries containing only organic polymers, but the preparation of flexible electrodes containing inorganic oxide materials still remains a challenge. ${ }^{18,19}$ The strategy of this work involves facile formation of the composite films by electrochemical polymerization of the pyrrole monomer in the $\mathrm{V}_{2} \mathrm{O}_{5}$ dispersed electrolyte solution, thereby obtaining composite films with high capacity and stability.

\section{Experimental}

$\mathrm{V}_{2} \mathrm{O}_{5}$ /PPy composite films were synthesized by an electrochemical polymerization of pyrrole on a stainless-steel (SS) gauze-electrode (SUS304-150 mesh, $90 \mu \mathrm{m}$ thick, $17 \mathrm{~mm}$ diameter disk) in an electrolyte solution $\left(0.1 \mathrm{M} \mathrm{LiClO}_{4}\right)$ containing both the pyrrole monomer $(0.20 \mathrm{M})$ and well-dispersed $\mathrm{V}_{2} \mathrm{O}_{5}$ particles $\left(14 \mathrm{mgmL}^{-1}\right)$. Following the method outlined, the $\mathrm{V}_{2} \mathrm{O}_{5} / \mathrm{PPy}$ composite films were grown on the SS substrate 
(gauze-electrode) under the application of an anodic potential of $+1.75 \mathrm{~V}$ versus $\mathrm{Ag} / \mathrm{AgCl}$ (saturated $\mathrm{KCl}$ solution) reference electrode. When the duration of the anodization was $10 \mathrm{~min}$, the thickness of the composite film became approximately $250 \mu \mathrm{m}$ (including the SS gauze thickness). In the same electrolyte solution, pyrrole was also polymerized to a powder form of PPy containing embedded $\mathrm{V}_{2} \mathrm{O}_{5}$ due to the catalytic action of $\mathrm{V}_{2} \mathrm{O}_{5}$.

The composition and the morphology of the $\mathrm{V}_{2} \mathrm{O}_{5} / \mathrm{PPy}$ composites were characterized by an FT-IR spectrophotometer [Nicolet iS10], a thermal gravity analyzer [Mac Science, MTC 1000], and a scanning electron microscope [SEM, JEOL JSM$6700 \mathrm{~F}$ ]. Cyclic voltammograms (CVs) were recorded using a Pine AFRDE4 Bi-potentiostat/galvanostat at a scan rate of 10 $\mathrm{mVs}^{-1}$ in a potential limit from 1.5 to $4.5 \mathrm{~V}$ in a three-electrode cell system with a $\mathrm{Li} / \mathrm{Li}^{+}$reference electrode, an $\mathrm{V}_{2} \mathrm{O}_{5} / \mathrm{PPy}$ composite film as working electrode, and a Pt-grid counter electrode. A 1.0 M lithium perchlorate in a propylene carbonate (PC) solution was used as the electrolyte; lithium perchlorate and PC were used after recrystallization and distillation, respectively. The batteries employed in this study were a series of the coin-type (CR2032) lithium rechargeable batteries based on the cathodes of the $\mathrm{V}_{2} \mathrm{O}_{5} / \mathrm{PPy}$ composite film, $\mathrm{V}_{2} \mathrm{O}_{5} / \mathrm{PPy}$ composite powder, and $\mathrm{V}_{2} \mathrm{O}_{5}$ powder. They were assembled in a dry room. The other parts of the assembled batteries were a lithiummetal plate as a negative electrode (anode) and a polypropylene (PP) separator soaked in a $1.0 \mathrm{M} \mathrm{LiPF}_{6}$ electrolyte solution in ethylene carbonate (EC)/dimethyl carbonate (DMC). The final form of the positive electrode for the coin-type Li cell was prepared by rolling the pristine $\mathrm{V}_{2} \mathrm{O}_{5} / \mathrm{PPy}$ composite film on the $\mathrm{SS}$ gauze. The thickness of the positive electrode was approximately $180 \mu \mathrm{m}$ including the SS gauze. The performance of these cathodes was tested using a battery test system (Maccor series 4000) and cycled galvanostatically in a multichannel battery test mode. In order to compare the battery characteristics of the $\mathrm{V}_{2} \mathrm{O}_{5} /$ PPy composite electrodes with $\mathrm{V}_{2} \mathrm{O}_{5}$ powder electrodes, $\mathrm{V}_{2} \mathrm{O}_{5}$ powder was mixed with acetylene carbon black and polytetrafluoroethylene (PTFE) binder to make the $\mathrm{V}_{2} \mathrm{O}_{5}$ electrodes without any conducting polymer. For the powder materials, a thin pellet (approximately $90 \mu \mathrm{m}$ thick after rolling) electrode was conventionally made using Doctor Blade method after slurrying in a solvent.

\section{Results and Discussion}

The $\mathrm{V}_{2} \mathrm{O}_{5} /$ PPy composite films were grown on the electrode surfaces in a solution of pyrrole containing dispersed $\mathrm{V}_{2} \mathrm{O}_{5}$ particles using the electrochemical oxidative polymerization method previously described. It is well known that $\mathrm{V}_{2} \mathrm{O}_{5}$ has the ability to oxidize pyrrole and that the oxidation of pyrrole should take place on the surface of the $\mathrm{V}_{2} \mathrm{O}_{5}$ particles. ${ }^{17}$ Additionally, the $\mathrm{V}_{2} \mathrm{O}_{5} /$ PPy composite powders were also produced from the same electrolyte solution. The $\mathrm{V}_{2} \mathrm{O}_{5}$ particles had dual functions: (i) as an oxidative catalyst for the polymerization of pyrrole in the electrolyte solution, and (ii) as an embedded particle component of the $\mathrm{V}_{2} \mathrm{O}_{5} / \mathrm{PPy}$ composite powders. All the composite films formed on the substrate-electrode and the composite powders formed in the electrolyte solution were in brownish-black color. This, coupled with SEM analysis, con-

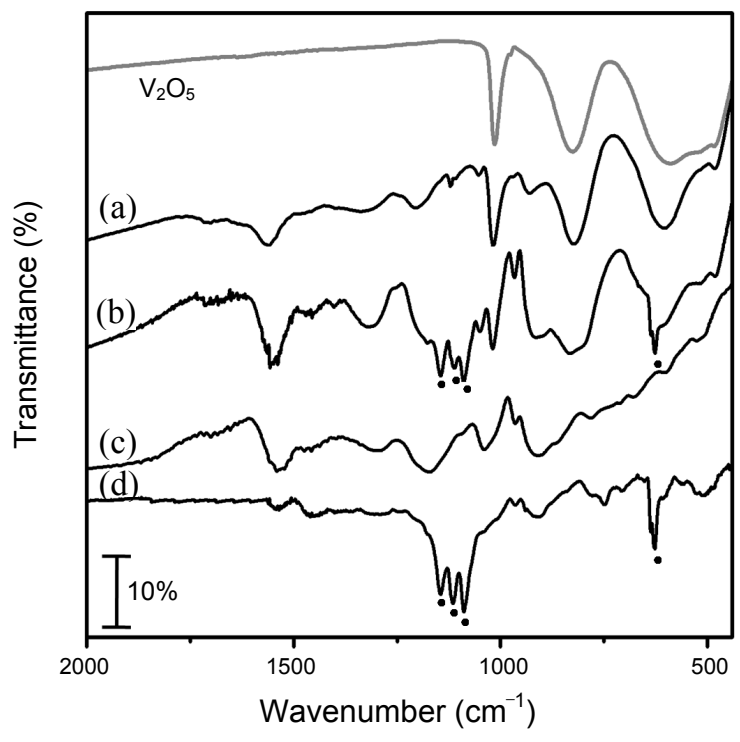

Figure 1. FT-IR spectra of (a) $\mathrm{V}_{2} \mathrm{O}_{5} / \mathrm{PPy}$ composite powder, (b) $\mathrm{V}_{2} \mathrm{O}_{5}$ / PPy composite film prepared by electrochemical method, (c) PPy-only powder prepared using catalyst $\left(\mathrm{FeCl}_{3}\right)$, and (d) PPy-only film prepared by electrochemical method using $\mathrm{LiClO}_{4}$ electrolyte solution.

firms the coating of PPy on the surface of the yellow colored $\mathrm{V}_{2} \mathrm{O}_{5}$ particles, i.e., PPy-coated $\mathrm{V}_{2} \mathrm{O}_{5}$. The structural, compositional, and morphological characterization of the $\mathrm{V}_{2} \mathrm{O}_{5} / \mathrm{PPy}$ composites has afforded insight into their electrochemical behavior as cathode materials. The IR spectra of $\mathrm{V}_{2} \mathrm{O}_{5} / \mathrm{PPy}$ composites are shown in Fig. 1. The $\mathrm{V}_{2} \mathrm{O}_{5} / \mathrm{PPy}$ composites exhibit the absorption bands of both $\mathrm{V}_{2} \mathrm{O}_{5}$ and PPy in their IR spectra (Figs. 1(a) and 1(b)). In the IR spectra of the $\mathrm{V}_{2} \mathrm{O}_{5} /$ PPy composites, the three main vibration bands of $\mathrm{V}_{2} \mathrm{O}_{5}$ are clearly visible at 1020,850 , and $600-480 \mathrm{~cm}^{-1}$, these correspond to the terminal oxygen symmetric stretching mode $\left(\mathrm{V}_{\mathrm{s}}\right)$ of $\mathrm{V}=\mathrm{O}$ and the bridge oxygen asymmetric and symmetric stretching modes ( $\mathrm{V}_{\mathrm{as}}$ and $\mathrm{v}_{\mathrm{s}}$ ) of $\mathrm{V}-\mathrm{O}-\mathrm{V}$, respectively. ${ }^{13-15}$ In addition, the characteristic bands of PPy in the $500-1600 \mathrm{~cm}^{-1}$ range confirms the presence of PPy in the composites. ${ }^{15-17}$ The IR spectrum of the PPy film prepared by the electrochemical oxidation method is different from that of the PPy powder prepared by a catalyst from the electrolyte solution (Figs. 1(c) and 1(d)). There are extra absorbance peaks in the IR spectrum for the PPy films grown electrochemically. The surplus peaks at 1145,1112 , 1089 , and $626 \mathrm{~cm}^{-1}$ indicate the presence of perchlorate ions $\left(\mathrm{ClO}_{4}{ }^{-}\right)$incorporated into the polypyrrole film (Figs. 1(b) and 1(d)). The presence of the perchlorate ions can be attributed to the charge compensation effect, which occurs during the oxidative growth of the polymer film at the oxidative electrode potential $(+1.75 \mathrm{~V})$. The nature and the concentration of the electrolyte anion are known to impact on both the quality and the physical properties of the films, due to the fact that electrolyte ions are also involved in the reactions during the reduction or oxidation reactions of polymers. ${ }^{10-12} \mathrm{The}_{2} \mathrm{O}_{5} / \mathrm{PPy}$ powder samples prepared by the catalytic action of $\mathrm{V}_{2} \mathrm{O}_{5}$ in the $\mathrm{LiClO}_{4}$ electrolyte solution do not show any absorption peaks indicative of the perchlorate ion. This result is similar to the PPy powder samples prepared by using other oxidative catalysts, 


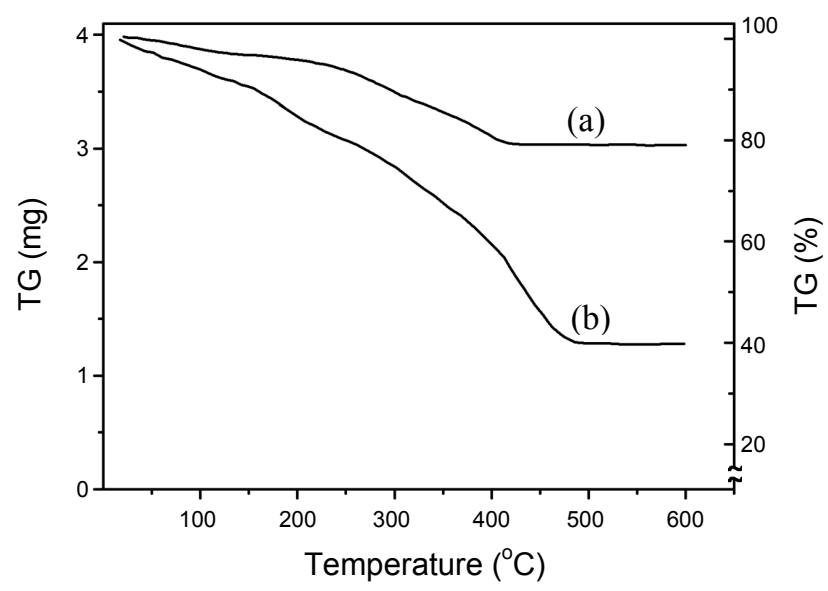

Figure 2. Thermogravimetric analysis of (a) $\mathrm{V}_{2} \mathrm{O}_{5} / \mathrm{PPy}$ composite powder $\left(\mathrm{V}_{2} \mathrm{O}_{5}: \mathrm{PPy}=80: 20\right)$ and $(\mathrm{b}) \mathrm{V}_{2} \mathrm{O}_{5} / \mathrm{PPy}$ composite film $\left(\mathrm{V}_{2} \mathrm{O}_{5}\right.$ : $\mathrm{PPy}=37: 73)$.

such as $\mathrm{FeCl}_{3}$ or ammonium persulfate, in a solution which contains no electrolyte. ${ }^{13-17}$ The relative intensities of the IR absorption bands corresponding to $\mathrm{V}_{2} \mathrm{O}_{5}$ and $\mathrm{PPy}$ indicate the relative amounts of each component in the $\mathrm{V}_{2} \mathrm{O}_{5}$ /PPy composites prepared. The relative absorption-band intensity of $\mathrm{V}_{2} \mathrm{O}_{5}$ to $\mathrm{PPy}$ of the composites is larger in the powder forms than in the film forms. The weight ratio of the $\mathrm{V}_{2} \mathrm{O}_{5} / \mathrm{PPy}$ composites was determined by thermogravimetric analysis (TGA). Since the combustion of the polymer is normally completed below $500{ }^{\circ} \mathrm{C}$, the $\mathrm{V}_{2} \mathrm{O}_{5}$ content in the composites is estimated from the TGA data, as shown in Fig. 2. The composition of the $\mathrm{V}_{2} \mathrm{O}_{5}$ /PPy powders obtained from the electrolyte solution corresponded to the amount of each component initially added to the solution; 80 $( \pm 0.5) \mathrm{wt} \%$ of $\mathrm{V}_{2} \mathrm{O}_{5}$. In the electrochemically prepared composite film, a $\mathrm{V}_{2} \mathrm{O}_{5}$ particle content of $37( \pm 5) \mathrm{wt} \%$ was obtained. The $\mathrm{V}_{2} \mathrm{O}_{5}$ content in the composite film electrodes prepared in this work was normally lower than that of the composite powders formed from the electrolyte.

SEM images of the $\mathrm{V}_{2} \mathrm{O}_{5} /$ PPy composites are shown in Fig. 3 . The irregular- or sphere-shape morphology of the $\mathrm{V}_{2} \mathrm{O}_{5} / \mathrm{PPy}$ composite films (Figs. 3(a) and 3(b)) is similar to the original irregular- or sphere-shape morphology of $\mathrm{V}_{2} \mathrm{O}_{5}$ (Figs. 3(c) and 3(d)). We did not observe any cauliflower-shaped or other shaped PPy lumps in the $\mathrm{V}_{2} \mathrm{O}_{5} / \mathrm{PPy}$ composite films. As shown in Fig. 3(e), the morphology of PPy film grown from pyrrole only typically shows a cauliflower-like shape. This work demonstrates that one can electrochemically synthesize composite films of conductive PPy with embedded $\mathrm{V}_{2} \mathrm{O}_{5}$ without employing an elaborate template or catalyst. Moreover, the $\mathrm{V}_{2} \mathrm{O}_{5} / \mathrm{PPy}$ composite powders can also be obtained from the electrolyte solution.

A series of cyclic voltammetric tests were performed on the composite films in an effort to evaluate the electrochemical properties of thus prepared $\mathrm{V}_{2} \mathrm{O}_{5} / \mathrm{PPy}$ composite films. Fig. 4 shows cyclic voltammograms $(\mathrm{CVs})$ of the $\mathrm{V}_{2} \mathrm{O}_{5} / \mathrm{PPy}$ composite film in the potential range of 1.5 and $4.5 \mathrm{~V}$ versus $\mathrm{Li} / \mathrm{Li}^{+}$reference electrode in $1.0 \mathrm{M} \mathrm{LiClO}_{4}$ propylene carbonate solution. The CVs obtained from the $\mathrm{V}_{2} \mathrm{O}_{5} / \mathrm{PPy}$ composite films exhibit

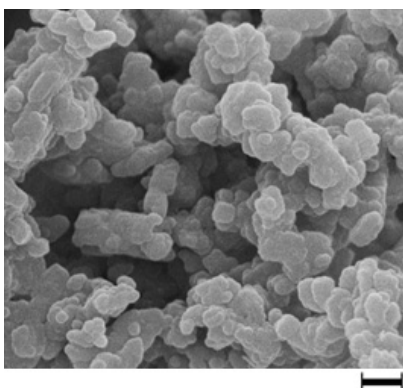

(a)

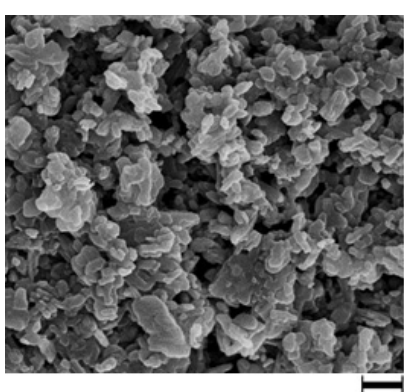

(c)

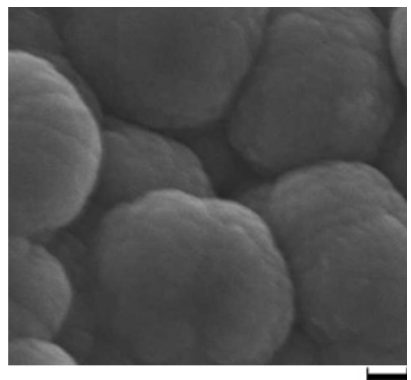

(e)

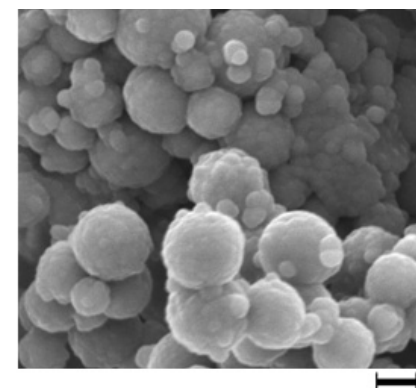

(b)

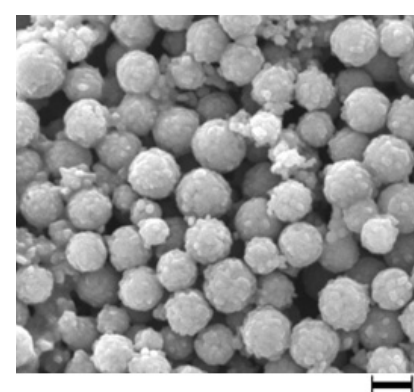

(d)
Figure 3. SEM images of (a) $\mathrm{V}_{2} \mathrm{O}_{5}$-irregular/PPy composite film, (b) $\mathrm{V}_{2} \mathrm{O}_{5}$-sphere/PPy composite film, (c) $\mathrm{V}_{2} \mathrm{O}_{5}$ irregular-shapes, (d) $\mathrm{V}_{2} \mathrm{O}_{5}$ spheres, and (e) electrochemical polypyrrole film. The scale bar indicates $1 \mu \mathrm{m}$.

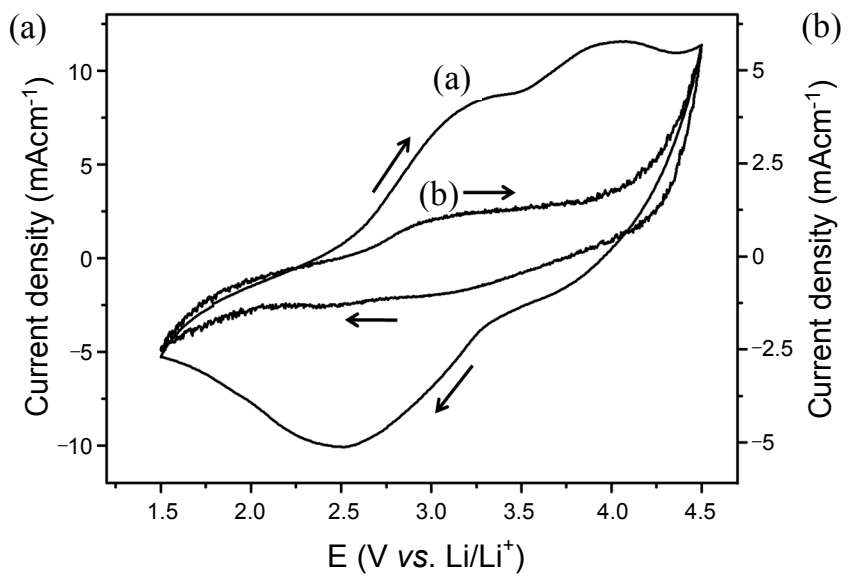

Figure 4. Cyclic voltammograms obtained in $1 \mathrm{M} \mathrm{LiClO}_{4}$ propylene carbonate solution at scan rate of $10 \mathrm{mVs}^{-1}$. The working electrode is the (a) $\mathrm{V}_{2} \mathrm{O}_{5} / \mathrm{PPy}(37: 73)$ composite film and (b) electrochemical PPyonly film. 


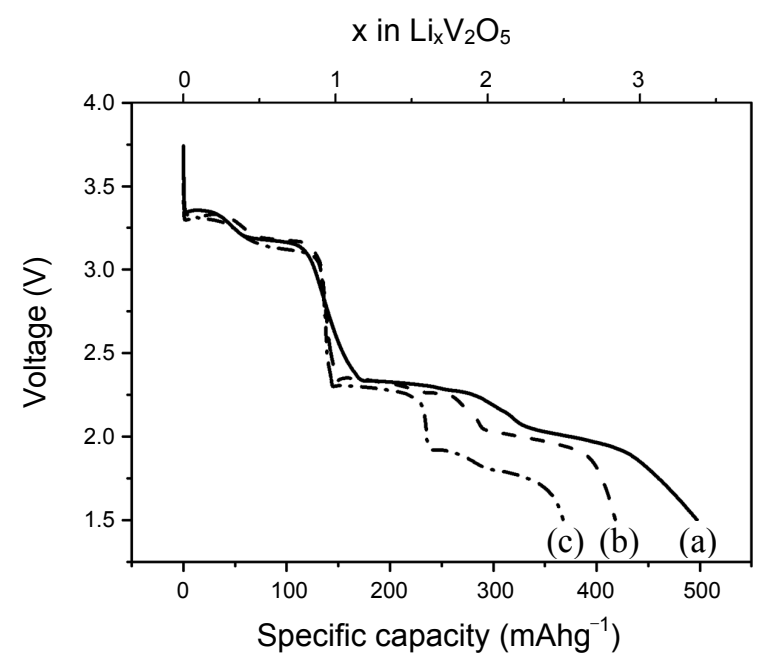

Figure 5. Initial discharge curves obtained from lithium batteries assembled with cathode of (a) $\mathrm{V}_{2} \mathrm{O}_{5} / \mathrm{PPy}$ composite film, (b) $\mathrm{V}_{2} \mathrm{O}_{5} / \mathrm{PPy}$ composite powder, and (c) pristine $\mathrm{V}_{2} \mathrm{O}_{5}$ powder.

broad anodic waves at approximately 3.2 and $3.8 \mathrm{~V}$ during the anodic scan from 1.5 to $4.0 \mathrm{~V}$, and cathodic waves at approximately 3.7 and $2.5 \mathrm{~V}$ during the cathodic scan from 4.0 to $1.5 \mathrm{~V}$. These two anodic waves correspond to two consecutive $\mathrm{Li}^{+}$ desertions from the composite film electrode. Similarly, the two cathodic waves can be attributed to two consecutive $\mathrm{Li}^{+}$insertions into the composite film electrode. This cyclic voltammogram confirms that the lithium ion can be quasi-reversibly intercalated (inserted) into and deintercalated from the vanadium oxide lattice, according to the following equation: $\mathrm{V}_{2} \mathrm{O}_{5}+$ $\mathrm{xLi}^{+}+\mathrm{xe}^{-} \Leftrightarrow \mathrm{Li}_{\mathrm{x}} \mathrm{V}_{2} \mathrm{O}_{5}$, at amounts of two equivalents $(\mathrm{x}=2)$ per $\mathrm{V}_{2} \mathrm{O}_{5}$, as previously reported. ${ }^{1-3}$ The $\mathrm{CV}$ of the PPy-only film electrode is also shown in Fig. 4(b) for a comparison. The PPy-only film reveals reversible anodic and cathodic waves at approximately $3 \mathrm{~V}$ with fairly low current.

The performance of the $\mathrm{V}_{2} \mathrm{O}_{5}$ /PPy composite film as a cathode for a Li battery was tested and compared with those of the $\mathrm{V}_{2} \mathrm{O}_{5} / \mathrm{PPy}$ composite powder and pristine $\mathrm{V}_{2} \mathrm{O}_{5}$ powder by assembling coin-type Li cells with a battery test system. During these tests, for the purpose of initial conditioning, the initial charge-discharge cycle was at a slow rate, $0.2 \mathrm{C}$, and the following two cycles were at $0.5 \mathrm{C}$ rate. The remaining 45 chargedischarge cycles were performed at $1.0 \mathrm{C}$ rate $\left(295 \mathrm{mAg}^{-1}\right)$. Fig. 5 shows these initial discharge curves of the lithium batteries assembled with cathodes of (a) the $\mathrm{V}_{2} \mathrm{O}_{5} / \mathrm{PPy}$ composite film, (b) the $\mathrm{V}_{2} \mathrm{O}_{5} / \mathrm{PPy}$ composite powder pellet, and (c) pristine $\mathrm{V}_{2} \mathrm{O}_{5}$ powder pellet. All these curves show multiple distinctive voltage plateaus, which are known to be related to the structural modifications of $\mathrm{V}_{2} \mathrm{O}_{5}$ induced by the lithium insertion during the discharging process. ${ }^{1,20}$ The voltage plateaus appearing at above $3 \mathrm{~V}$ correspond to the structural modifications from $\mathrm{V}_{2} \mathrm{O}_{5}$ to $\mathrm{Li}_{\mathrm{x}} \mathrm{V}_{2} \mathrm{O}_{5}$ up to one equivalent $(\mathrm{x}=1) \mathrm{Li}^{+}$insertion. Regardless of the curves for the (a) $\mathrm{V}_{2} \mathrm{O}_{5} / \mathrm{PPy}$ composite film, (b) $\mathrm{V}_{2} \mathrm{O}_{5} / \mathrm{PPy}$ composite powder pellet, or (c) pristine $\mathrm{V}_{2} \mathrm{O}_{5}$ powder pellet, these plateaus are approximately extended to the same specific capacity value of $147 \mathrm{mAhg}^{-1}$. The additional potential plateaus that appear at the lower voltage levels are

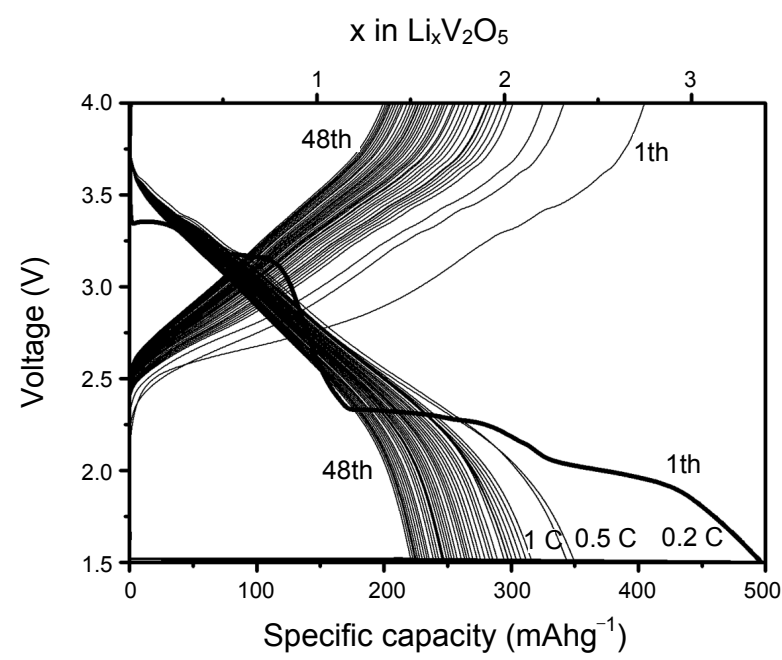

Figure 6. Charge-discharge plot of 48 full cycles for lithium batteries assembled with cathode of $\mathrm{V}_{2} \mathrm{O}_{5} / \mathrm{PPy}$ composite film. For the purpose of initial conditioning, the first charge-discharge cycle was at $0.2 \mathrm{C}$ rate and the following two cycles at $0.5 \mathrm{C}$ rate. The remaining 45 cycles were all at $1 \mathrm{C}$ rate $\left(295 \mathrm{mAg}^{-1}\right)$.

attributed to the structural modifications related to $\mathrm{Li}^{+}$insertion of greater than one equivalent. The plateaus in the vicinity of $2.3 \mathrm{~V}$ for the (a) $\mathrm{V}_{2} \mathrm{O}_{5} /$ PPy composite film, (b) $\mathrm{V}_{2} \mathrm{O}_{5} / \mathrm{PPy}$ composite powder pellet, and (c) pristine $\mathrm{V}_{2} \mathrm{O}_{5}$ powder pellet are extended to the specific capacity values of approximately 292, 270, and $235 \mathrm{mAhg}^{-1}$, respectively. Considering that the theoretical limits of the specific capacities of $\mathrm{V}_{2} \mathrm{O}_{5}$ for one equivalent and two equivalents of $\mathrm{Li}^{+}$intercalation are 147 and 295 $\mathrm{mAhg}^{-1}$ respectively, it is worth mentioning that the $\mathrm{V}_{2} \mathrm{O}_{5} / \mathrm{PPy}$ composite film case is reaching the theoretical limits in both one and two equivalents. Further discharge of the batteries leads to another plateau at approximately $2.0 \mathrm{~V}$ with an electrochemical insertion above two equivalents of $\mathrm{Li}^{+}$into the lattices and the ensuing the formation of $\mathrm{Li}_{3} \mathrm{~V}_{2} \mathrm{O}_{5}\left(\mathrm{x}=3\right.$ for $\left.\mathrm{Li}_{\mathrm{x}} \mathrm{V}_{2} \mathrm{O}_{5}\right)$ during the first discharging process to the extended potential range. As shown in Fig. 5 for three initial discharge curves (a) (b) and (c), the plateaus in the vicinity of $2.0 \mathrm{~V}$ are extended to the specific capacity values of approximately 497,418 , and 368 $\mathrm{mAhg}^{-1}$, respectively. The specific capacities for the composite cases of (a) and (b) are significantly higher than the values reported in Refs. 1-3, 20-23, which reported $400 \mathrm{mAhg}^{-1}$ as the highest discharge specific capacity for cathodes comprising of various forms of $\mathrm{V}_{2} \mathrm{O}_{5}$.

It can be seen in Fig. 5 that, compared to the pristine $\mathrm{V}_{2} \mathrm{O}_{5}$, the $\mathrm{V}_{2} \mathrm{O}_{5} / \mathrm{PPy}$ composite powder has the higher specific capacity throughout the whole initial discharge curves. Conductive PPy polymer in the $\mathrm{V}_{2} \mathrm{O}_{5} /$ PPy composite powder electrode evidently has aided with the $\mathrm{Li}^{+}$insertion into the $\mathrm{Li}_{\mathrm{x}} \mathrm{V}_{2} \mathrm{O}_{5}$ lattice of the composite electrode, by improving both the accessibility of $\mathrm{Li}^{+}$ ion and the electrical conductivity. Conductive polymers in the composite films can connect the isolated $\mathrm{V}_{2} \mathrm{O}_{5}$ particles and give rise to valid conductive networks in the electrodes. Furthermore, the $\mathrm{V}_{2} \mathrm{O}_{5} / \mathrm{PPy}$ composite film possesses the greatest specific capacity, indicating that the conductive PPy polymer film formed by the electrochemical method is even more effi- 


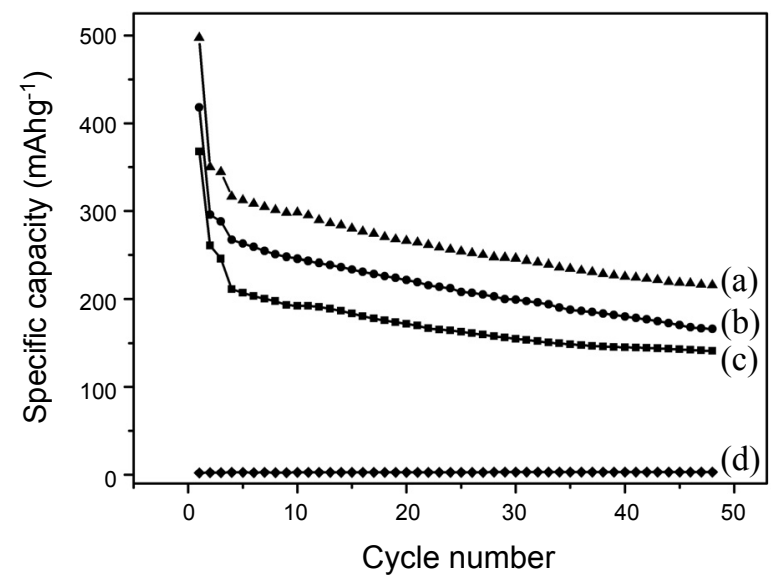

Figure 7. Specific capacities of lithium batteries assembled with cathode of (a) $\mathrm{V}_{2} \mathrm{O}_{5} /$ PPy composite film, (b) $\mathrm{V}_{2} \mathrm{O}_{5} /$ PPy composite powder, (c) pristine $\mathrm{V}_{2} \mathrm{O}_{5}$ powder, and (d) PPy-only film. For the purpose of initial conditioning, the first charge-discharge cycle was at $0.2 \mathrm{C}$ rate and the following two cycles at $0.5 \mathrm{C}$ rate. The remaining 45 cycles were all at $1 \mathrm{C}$ rate $\left(295 \mathrm{mAg}^{-1}\right)$.

cient at promoting $\mathrm{Li}^{+}$insertion/desertion into/from the $\mathrm{Li}_{\mathrm{x}} \mathrm{V}_{2} \mathrm{O}_{5}$ lattice. This effect will be further discussed in conjunction with Fig. 7.

Fig. 6 shows the consecutive 48 charge-discharge cycles of the battery assembled with the $\mathrm{V}_{2} \mathrm{O}_{5} / \mathrm{PPy}$ composite film cathode. In this figure, " $1 \mathrm{st}$ " denotes the initial charge-discharge cycle as illustrated in Fig. 5, which shows the distinct voltage plateaus correlated to the structural changes induced by the lithium insertion for any cathodes in composite-film or powder forms. However, these structural changes are evidently the irreversible desertion/insertion process of the $\mathrm{Li}^{+}$ions in the case of the $\mathrm{V}_{2} \mathrm{O}_{5} / \mathrm{PPy}$ composite film as shown in the second and subsequent discharge curves in Fig. 6 . The distinct voltage plateaus have almost disappeared by the time the 48th cycle is reached. The decrease in the capacities of the cathode, also shown in Fig. 7(a), can be considered a direct result of the irreversible $\mathrm{Li}^{+}$insertion/desertion into/from the $\mathrm{V}_{2} \mathrm{O}_{5}$ lattices. In spite of the large values of the specific capacities obtained for the $\mathrm{V}_{2} \mathrm{O}_{5} / \mathrm{PPy}$ composite-cathodes owing to the synergistic effect of the inorganic material and the conductive organic polymer, the capacities of the batteries composed of the $\mathrm{V}_{2} \mathrm{O}_{5} / \mathrm{PPy}$ composite cathodes also fade during repeated charge/discharge cycles similar to that of the $\mathrm{V}_{2} \mathrm{O}_{5}$ cathode. The capacity loss from 317 to $221 \mathrm{mAhg}^{-1}$ between the 4 th and 48 th cycles at $1 \mathrm{C}$ rate was observed for the $\mathrm{V}_{2} \mathrm{O}_{5} / \mathrm{PPy}$ composite film cathode. A similar or more severe decline in the capacity has also been reported upon cycling the lithium batteries composed of $\mathrm{V}_{2} \mathrm{O}_{5}$ xerogel, amorphous vanadium pentoxides, or crystalline $\mathrm{V}_{2} \mathrm{O}_{5}$ cathodes. $^{20,21}$ The irreversible structural changes induced by redox cycling are considered to be the crucial factor for the capacity loss of the $\mathrm{V}_{2} \mathrm{O}_{5}$ cathode. This is especially true if the discharging/charging occurs over an extremely wide range of voltage, since this can cause a large loss of capacitance accompanied by irreversible phase transformation with electron transfers of several steps.
Fig. 7 shows the specific discharge (lithium-insertion) capacities recorded for the 48 consecutive charge-discharge cycles of the battery assembled using cathodes of (a) the $\mathrm{V}_{2} \mathrm{O}_{5} / \mathrm{PPy}$ composite film, (b) the $\mathrm{V}_{2} \mathrm{O}_{5} / \mathrm{PPy}$ composite powder pellet, (c) the pristine $\mathrm{V}_{2} \mathrm{O}_{5}$ powder pellet, and (d) PPy-only film. The specific capacity values of the 48th discharging for these four cathodes from (a) to (d) are 221, 168, 143, and $3 \mathrm{mAhg}^{-1}$, respectively. The cells composed of the $\mathrm{V}_{2} \mathrm{O}_{5} / \mathrm{PPy}$ composite film and $\mathrm{V}_{2} \mathrm{O}_{5} /$ PPy composite powder cathodes exhibit higher capacities than that of the battery composed of the pristine $\mathrm{V}_{2} \mathrm{O}_{5}$ cathode. The differences are much larger than the specific capacity of PPy-only film itself (approximately $3 \mathrm{mAhg}^{-1}$ ). Thus it can be concluded that the contribution to the capacity from the oxidation and reduction of polypyrrole itself to the redox current of the composite electrode is small when compared to the contribution of $\mathrm{V}_{2} \mathrm{O}_{5}$ in the $\mathrm{V}_{2} \mathrm{O}_{5} / \mathrm{PPy}$ composite films. Rather, the mechanically flexible, electrically conductive, and electrochemically active organic polymers enhance the specific capacities by connecting isolated $\mathrm{V}_{2} \mathrm{O}_{5}$ particles thus, creating valid conductive networks for lithium ions and/or counter anions of the electrolyte for the electrode. This enables increased activation of the isolated $\mathrm{V}_{2} \mathrm{O}_{5}$ particles and allows them to be employed for the lithium intercalation/deintercalation in the composite film during the battery cycling. In addition, the polypyrrole itself is also oxidized and reduced involving lithium ions or counter anions of the electrolyte. Owing to the synergistic effect (discussed above) between the inorganic and organic components of the composite films, the $\mathrm{V}_{2} \mathrm{O}_{5} / \mathrm{PPy}$ composites possess significantly larger specific capacities compared to the simple algebraic summation of the specific capacities of the pristine $\mathrm{V}_{2} \mathrm{O}_{5}$ and PPy. This synergistic effect is evidently further emphasized in the case of the electrochemically formed film as shown in Figs. 5(a) and 7(a), compared to the case of the powder as shown in Figs. 5(b) and 7(b). This interesting phenomenon is initially attributed to the enhanced diffusion of lithium to the surface of the isolated $\mathrm{V}_{2} \mathrm{O}_{5}$ particles and increased the accessibility of the lithium ion. However, further investigations are underway in this work.

\section{Conclusions}

In this work, $\mathrm{V}_{2} \mathrm{O}_{5} / \mathrm{PPy}$ composite films have been synthesized by an electrochemical method. Charge/discharge cycling data of a rechargeable Li battery have shown that the $\mathrm{V}_{2} \mathrm{O}_{5} / \mathrm{PPy}$ composite films can be potentially used as high-capacity cathode materials with an initial discharging capacity of $497 \mathrm{mAhg}^{-1}$ (at $0.1 \mathrm{C}$ rate) and a 48 th discharging capacity of $221 \mathrm{mAhg}^{-1}$ (at $1 \mathrm{C}$ rate). The composites consisting of a layer-structured metal oxide and a conducting polymer result in a synergistic interaction between the inorganic and organic components. The $\mathrm{V}_{2} \mathrm{O}_{5} / \mathrm{PPy}$ composite electrodes have higher specific capacities than the $\mathrm{V}_{2} \mathrm{O}_{5}$ electrode for $\mathrm{Li}$ batteries owing to the improved electronic conductivity and the enhanced lithium-ion accessibility in the cathode. The conductive polymers in the composites efficiently connect the isolated $\mathrm{V}_{2} \mathrm{O}_{5}$ particles, resulting in the formation of conductive networks in the electrode. Thus, a synergistic interaction between the inorganic and organic components of the $\mathrm{V}_{2} \mathrm{O}_{5} /$ PPy composites is evident. 
Acknowledgments. This work was supported by the National Research Foundation of Korea (2009-0083734 and 20090094049).

\section{References}

1. Delmas, C.; Cognac-Auradou, H.; Cocciantelli, J. M.; Menetrier, M.; Doumerc, J. P. Solid State Ionics. 1994, 69, 257.

2. West, K.; Zachau-Christiansen, B.; Jacobsen, J.; Shaarup, S. Solid State Ionics. 1995, 76, 15

3. Desilvestro, J.; Haas, O. J. Electrochem. Soc. 1990, 137, 5C.

4. Arico, A. S.; Bruce, P.; Scrosati, B.; Tarascon, J.-M.; Van Schalkwijk, W. Nature Mater. 2010, 4, 366.

5. Reddy, Ch. V. S.; Park, K.-I.; Mho, S.-I.; Yeo, I.-H.; Park, S.-M. Bull. Korean Chem. Soc. 2008, 29, 2061.

6. Giorgetti, M.; Passerini, S.; Smyrl, W. H.; Berrettoni, M. Inorg. Chem. 2000, 39, 1514.

7. Petkov, V.; Trikalitis, P. N.; Bozin, E. S.; Billinge, S. J. L.; Vogt, T.; Kanatzidis, M. G. J. Am. Chem. Soc. 2002, 124, 10157.

8. Malinauskas, A.; Malinauskiene, J.; Ramanavicius, A. Nanotechnology 2005, 16, R51.

9. Sadki, S.; Schottland, P.; Brodie, N.; Sabouraud, G. Chem. Soc. Rev. 2000, 29, 283.

10. Duchet, J.; Legras, R.; Demoustier-Champagne, S. Synth. Met.
1998, 98,113

11. Song, M.-K.; Park, J.-K.; Yeo, I.-H.; Rhee, H.-W. Synth. Met. 1999, 99, 219.

12. Chung, S.-M.; Paik, W.-K.; Yeo, I.-H. Synth. Met. 1997, 84, 155.

13. Goward, G. R.; Lerous, F.; Nazar, L. F. Electrochim. Acta 1998, 43, 1307.

14. Demets, G. J. F.; Anaissi, F. J.; Toma, H. E. Electrochim. Acta 2000, 46, 547 .

15. Boyano, I.; Bengoechea, M.; de Meatza, I.; Miguel, O.; Cantero, I.; Ochoteco, E.; Rodriguez, J.; Lira-Cantu, M.; Gomez-Romero, P. J. Power Sources 2007, 166, 471.

16. Kuwabata, S.; Masui, S.; Tomiyori, H.; Yoneyama, H. Electrochim. Acta 2000, 46, 91.

17. Huguenin, F.; Girotto, E. M.; Torresi, R. M.; Buttry, D. A. J. Electroanal. Chem. 2002, 536, 37 .

18. Suga, T.; Ohshiro, H.; Sugita, S.; Oyaizu, K.; Nishide, H. Adv. Mater. 2009, 20, 1

19. Armand, M.; Tarascon, J.-M. Nature 2008, 451, 652.

20. Mho, S.-I.; Reddy, Ch. V. S.; Kim, Y.; Yeo, I.-H.; Park, S.-M. J. Korean Phys. Soc. 2009, 54, 2420.

21. Wang, Y.; Takahashi, K.; Lee, K.; Cao, G. Adv. Funct. Mater. 2006, 16, 1133.

22. Tarascon, J.-M.; Armand, M. Nature 2001, 414, 359.

23. Whittingham, M. S. Chem. Rev. 2004, 104, 4271. 